\title{
Monitoring of the technical requirements compliance in the Solid Household Waste landfills functioning through the method of visual detection
}

\author{
Andrey Richter ${ }^{1, *}$, Maretta Kazaryan $^{2}$, and Michael Shahramanyan ${ }^{1}$ \\ ${ }^{1}$ Researching Institute “AEROCOSMOS”, 105064, Moscow, Russia \\ ${ }^{2}$ Financial University at Government of Russian Federation Vladikavkaz branch, 362001 Vladikavkaz, Russia
}

\begin{abstract}
The paper describes the method of visual detection in the task of assessing compliance with the requirements for the design, operation and reclamation of landfills for solid domestic waste. An example of verification of requirements for landfills is given in accordance with the instruction on design, operation and reclamation. It is shown, in particular, the construction of a sanitary protection zone in the Google Earth program for assessing the permissibility of natural and anthropogenic objects it includes. The series of basic concepts associated with visual detection of solid waste landfills are given, and namely, a number of soil elements that can be detected by the method of visual detection are described.
\end{abstract}

\section{Introduction}

The solution of the problem of littering belongs to more than one generation of humanity, and its relevance will only grow with the time. In the study of the problem under consideration, a certain mathematical apparatus is used [6-10]. But you can start solving this long-term emergency situation right now by setting a point of support both inside yourself (i.e., changing the inner world, consciousness) and outside (ie changing the external world, i.e., the environment around you). Internal change is purely individual, and the external one can be given a logical explanation. The later, in particular, includes the monitoring of Waste Disposal Sites (WDSs) with the imparting of some power impulse (in a physical, economic, social aspect).

The advantage of classical algorithms of space monitoring is the automation of image processing, i.e. a large-scale survey of the area of observation using space images. But the reverse side of this "coin" is their main disadvantage - the limited possibilities for examining the area. Most of the information is not extracted from the image. In this regard, a method of visual detection of WDSs is suggested, in which a wider range of problems can be solved, but on a more narrow scale. For example, the state of the environment in a solid waste landfill from the point of view of visual detection can be assessed in various ways, in particular: 1) areas occupied by vegetation and their variation over time; 2) soil degradation: bogging, salinization, etc. [5]; 3) changes in the object composition of the territory; 4) abnormal zones in the vicinity of the WDS; 5) compliance with the Rules of Design, Operation and Reclamation (RDOR) of the WDS; 6) quality of vegetation.
Requirements for solid waste landfills, estimated by the method of visual detection.

Observance of many PDOR rules (see [4]) can be verified by visualization of cosmic images. Comparison of these data with field observations, of course, will give a more ambitious and qualitative result.

Table 1. Design Requirements.

\begin{tabular}{|l|r|r|}
\hline Requirement & \multicolumn{2}{|c|}{$\begin{array}{l}\text { Control of compliance with the } \\
\text { use of detection technologies }\end{array}$} \\
\cline { 2 - 3 } & Visual & Automatic \\
\hline $\begin{array}{l}\text { Availability and } \\
\text { layout of the main } \\
\text { facilities of the } \\
\text { landfill }\end{array}$ & + & + \\
\hline $\begin{array}{l}\text { Relation of the } \\
\text { terrain and the } \\
\text { polygon filling } \\
\text { scheme }\end{array}$ & + & \\
\hline $\begin{array}{l}\text { Drainage ditch, tree } \\
\text { planting design }\end{array}$ & & \\
\hline $\begin{array}{l}\text { Designing of the } \\
\text { foundation ditches } \\
\text { of polygons }\end{array}$ & + & \\
\hline $\begin{array}{l}\text { Designing of the } \\
\text { base shields }\end{array}$ & + & \\
\hline $\begin{array}{l}\text { Monitoring of the } \\
\text { sanitary protection } \\
\text { zone }\end{array}$ & + & \\
\hline $\begin{array}{l}\text { Distance to the } \\
\text { nearest town- } \\
\text { planning objects }\end{array}$ & + & \\
\hline
\end{tabular}

\footnotetext{
* Corresponding author: urfin17@yandex.ru
} 
Table 2. Operating Requirements

\begin{tabular}{|c|c|c|}
\hline \multirow[t]{2}{*}{ Requirement } & \multicolumn{2}{|c|}{$\begin{array}{l}\text { Monitoring the fulfillment of } \\
\text { requirements using detection } \\
\text { technologies }\end{array}$} \\
\hline & Visual & Automatic \\
\hline $\begin{array}{l}\text { Organization of } \\
\text { storage } \\
\text { (area, volume, } \\
\text { order, rate of } \\
\text { filling) }\end{array}$ & + & + \\
\hline $\begin{array}{l}\text { Availability of } \\
\text { household, } \\
\text { construction, } \\
\text { industrial waste; } \\
\text { volumes }\end{array}$ & + & + \\
\hline $\begin{array}{l}\text { Wetting of waste in } \\
\text { fire hazardous } \\
\text { periods }\end{array}$ & + & - \\
\hline $\begin{array}{l}\text { The order of work } \\
\text { (development, } \\
\text { backfilling, } \\
\text { consolidation) }\end{array}$ & + & $=$ \\
\hline $\begin{array}{l}\text { The presence and } \\
\text { composition } \\
\text { of intermediate } \\
\text { screens (surfaces } \\
\text { and slopes) }\end{array}$ & + & - \\
\hline $\begin{array}{l}\text { The presence of } \\
\text { cluttering } \\
\text { neighborhoods }\end{array}$ & + & + \\
\hline $\begin{array}{ll}\text { Backfilling } & \text { with } \\
\text { vegetable } & \text { soil, } \\
\text { gardening } & \end{array}$ & & + \\
\hline $\begin{array}{l}\text { Quality of waste } \\
\text { insulation from the } \\
\text { environment }\end{array}$ & + & - \\
\hline $\begin{array}{l}\text { Availability of } \\
\text { hazardous waste }\end{array}$ & + & $=$ \\
\hline $\begin{array}{l}\text { Stage of } \\
\text { degradation, } \\
\text { humification, } \\
\text { assessment of the } \\
\text { composition of the } \\
\text { landfill }\end{array}$ & + & $=$ \\
\hline $\begin{array}{l}\text { Coating with final } \\
\text { protective screens } \\
\text { (surfaces, slopes) }\end{array}$ & + & + \\
\hline
\end{tabular}

Table 3. Requirements for reclamation

\begin{tabular}{|c|c|c|}
\hline \multirow[t]{2}{*}{ Requirement } & \multicolumn{2}{|c|}{$\begin{array}{l}\text { Control of compliance with } \\
\text { the use } \\
\text { of detection technologies }\end{array}$} \\
\hline & Visual & Automatic \\
\hline $\begin{array}{l}\text { Availability of } \\
\text { storage of waste }\end{array}$ & + & + \\
\hline $\begin{array}{ll}\text { Backfilling } & \text { with } \\
\text { vegetable } & \text { soil, } \\
\text { gardening } & \end{array}$ & + & + \\
\hline $\begin{array}{l}\text { Planting trees and } \\
\text { shrubs on the slopes }\end{array}$ & + & + \\
\hline $\begin{array}{l}\text { Coverage of } \\
\text { technological } \\
\text { and biological } \\
\text { remediation screens }\end{array}$ & + & - \\
\hline $\begin{array}{l}\text { Quality of technical } \\
\text { reclamation }\end{array}$ & + & - \\
\hline $\begin{array}{l}\text { Quality of } \\
\text { biological } \\
\text { reclamation }\end{array}$ & + & $=$ \\
\hline $\begin{array}{l}\text { Quality of work } \\
\text { (agricultural, } \\
\text { forestry and } \\
\text { construction) for the } \\
\text { further use of land }\end{array}$ & + & $=$ \\
\hline
\end{tabular}

Let's consider some PDOR rules, which can be checked by the method of visual detection. Tables 1-3 show a number of requirements for the design, operation, and remediation, respectively, of landfills for solid domestic wastes (SDW) and Industrial Wastes (IW) using space monitoring technologies [1]. The sign "+" marks the developed technologies, the sign "-" - the technologies that require refinement.

One of the advantages of visual detection before automatic is the ability to test a larger set of PDOR rules (see tables 1-3). But at the same time there are restrictions on the number and quality of available satellite imagery. To verify many requirements, high resolution images and their high frequency ( 1 time per month) are required, which is possible in rare cases. Many images are of medium resolution, in many cases neighboring chronological images are separated from each other by several years according to the date of shooting.

\section{Example of verification of compliance with the requirements of solid waste landfills}

In accordance with [4], among the rules of SanitaryProtective Zone (SPZ) are the following: 


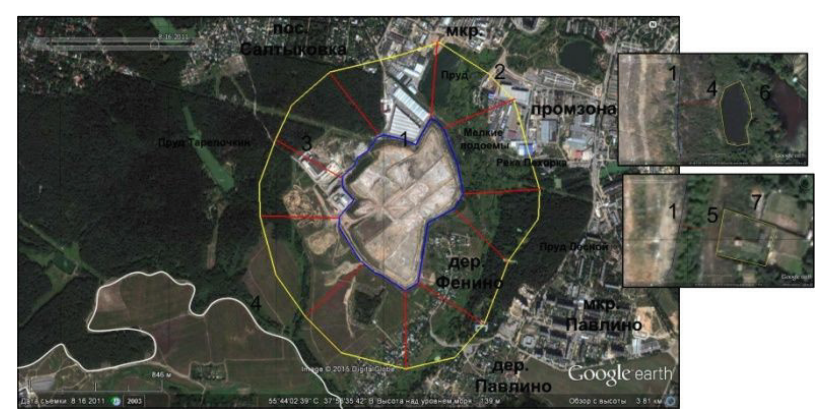

Fig.1 Identification of violations of the rules of the SPZ of the landfill of Kuchino

1. "Landfills are located outside of cities and other settlements. The size of the SPZ from residential buildings to the landfill boundaries is $500 \mathrm{~m}$. Moreover, the size of the sanitary protection zone (SPZ) is specified in the calculation of gaseous emissions. The boundaries of the zone are established by isolating 1 of the maximum permissible concentrations, if it leaves the limits of the regulatory zone. The size of the zone less than $500 \mathrm{~m}$ not allowed "(paragraph 1.2). Source: [4];

2. " It is prohibited to place residential buildings , industrial wells and wells for drinking purposes in the SPZ of the landfill. In the absence of green plantations or earth embankments in the SPZ, cavaliers of the ground necessary for insulation at its closure are arranged along the perimeter of the landfill. The SPZ regime is determined by the current rules and regulations "(paragraph 1.29). Source: [4].

Thus, the nearest residential house and the source of drinking water must be located at a distance of at least 500 $\mathrm{m}$ from the boundaries of the storage site. Then conditionally, SPZ can be constructed parallel to the boundary of the storage site at a distance of $500 \mathrm{~m}$ from it (Figure 1). Then some violations / compliance with the SPZ rules will be identified, which can be counted individually or by the area of violations / observance of the SPZ rules.

In Figure 1: 1 - the boundary of the storage area [2], 2 - the boundary of the SPZ, 3 - the radius of $500 \mathrm{~m}$ of the SPZ. It can be seen from figure 1 that several water sources are lying inside the SPZ (the Pekhorka River, the Lesnoy Pond, etc.), as well as parts of several settlements. These include: the village. Feninoand the village. Saltykovka (insignificant part); a small part of the industrial zone located in the city Zheleznodorozhny; almost the entire area of the village. Fenino. In addition, the boundary of the SPZ of the polygon is close to the Moscow border and is approaching it with time. The minimum distances to objects of different classes are also violated, in particular, for water sources and residential buildings: 4 - distance to the nearest water source $(40 \mathrm{~m})$, 5 - distance to the nearest residential building $(20 \mathrm{~m}), 6$ nearest water body, 7 - the nearest building.

An important factor in assessing compliance with requirements is the designation of the concepts governed in the document [4] on images. Studies have shown that these concepts can be divided into groups: Elements of the soil; Structural elements of the landfill; Operations at PDOR of Solid Domestic Waste landfills.
The main operations at any stage of the life of the landfill (design, operation or reclamation) are excavation [3]. This work includes the development, movement, laying and compaction of soil; the formation of embankments and depressions. Elements of the soil include:

- mound - an artificial form of relief in the form of an elevation of land and / or waste;

- excavation - an artificial form of relief in the form of a lowering of the earth;

- half-pouring (half-pit) - an artificial form of relief in the form of elevations from the earth, alternating with artificial depressions of the earth;

- shaft - high earthen mound, usually with a moat in front, erected for the purpose of localizing waste;

- career - a notch intended for filling with waste and being a constituent of a solid waste landfill;

- $\quad$ pit - a deep pit, a foundation dug for mining purposes;

- dump pit - a mound of excavated material removed from the excavation, laid behind the slope of the excavation, which is not used to construct the mound in another place;

- $\quad$ cascade - the structure of the depressions formed by the queue of operation;

- $\quad$ base (bottom) - part of the surface of the notch with a slope of less than $0.5 \%$.

The base of the test site is the base (base) of a ditch or ravine dug for it; slope - part of the surface of the excavation and embankment with a slope of more than $0.5 \%$; ravine is a natural form of relief in the form of relatively deep and steeply inclined unclosed troughs formed by temporary streams; trench - an open excavation in the soil of a trapezoidal section with a depth of 3-6 m, a width of 6-12 m and a length that is dependent on the temperature and amount of imported waste; ditch - recess length, much greater than the width used to drain the liquid; dam - a mound of length, much greater than the width, used as a temporary road. Separates the cascade notches.

- The base of the test site is the base (base) of a ditch or ravine dug for it;

- slope is a part of the surface of the excavation and embankment with a slope of more than $0.5 \%$;

- ravine is a natural form of relief in the form of relatively deep and steeply inclined unclosed troughs formed by temporary streams;

- trench is an open excavation in the soil of a trapezoidal section with a depth of 3-6 m, a width of 6-12 $\mathrm{m}$ and a length that is dependent on the temperature and amount of imported waste;

- ditch is the recess length, much greater than the width used to drain the liquid;

- dam is a mound of length, much greater than the width, used as a temporary road. It separates the cascade notches.

The structural elements of the landfill include:

- the queue - part of the storage area, designed for operation by an economic entity for 3-5 years;

- tier - a layer of waste $2-2.5 \mathrm{~m}$ thick after the compaction operation; 
- a temporary road is a road used by machines for storing solid waste.

The working card is the SDW storage area allocated for the given day. Width is $5 \mathrm{~m}$ (bulk map), $12 \mathrm{~m}$ (trench), length is $30-150 \mathrm{~m}$; fence - is an artificial structure that describes the boundaries of a solid domestic waste landfill, an economic zone and / or a landfill site. Among others are:

- a slope,

- serpentine,

- screening,

- protective screens and other concepts.

Screening is the protection from the negative impact on the environment of certain dangerous or harmful factors, in particular, littering [3]. Screening is provided by protective screens, which, in turn, can be natural or artificial.

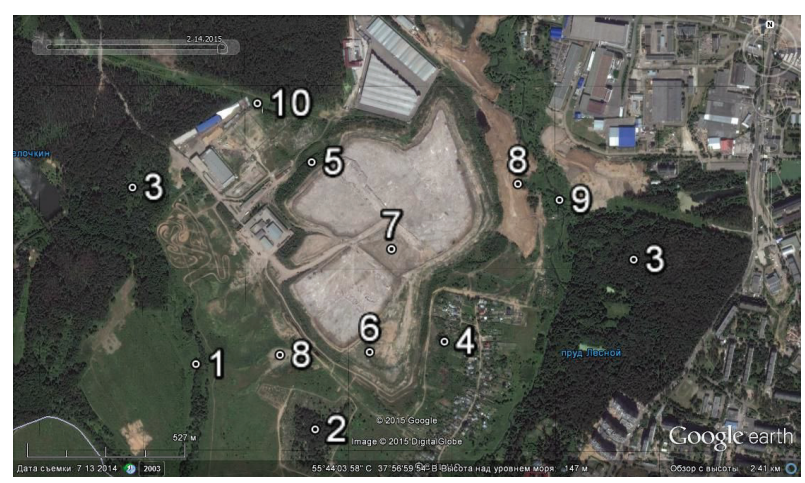

Fig.2 Shielding forms in the vicinity of the landfill of Kuchino

Natural screens are formed without the participation of man under the influence of the forces of nature. For example, a forest is a natural screen of solid waste landfills, which can grow on its own, if it is not cut down. The forest screen (see Figure 2) takes the form of a forest belt (1), a forest plant (2) or a forest in general (3), plantations (4), grass borders and trees of the storage site, vegetation cover of the slopes of the landfill (5). Covering old areas of storing with grass and / or forest vegetation (6) can also be attributed to natural screens.

Different screens have different composition, purpose and carry different protective functions, and not always favorable for environment. For example, the river 9, which runs along the landfill, screens the spread of the filtrate through the soil, but, in its turn, transports the filtration water. Forest plantations of 4 suburban areas delay the spread of the filtrate, but at the same time they experience significant anthropogenic load. Snow refers to natural time screens operating during the cold season. This screen has rehabilitating functions and restores annually, as far as possible, the soil structure [5].

To reduce the negative impact of littering on the environment, natural screens are not enough. Therefore, they resort to artificial ones. Figure 2 shows: 7 - covering of waste with a layer of soil, 8 - ground dump pit, also for delaying soil degradation, 10 - artificial fences for a solid waste landfill (fence).

The rules, as you know, can not only be violated, but also be respected. For example, backfilling with a dump pit of soil as an anti-filter screen (see 8 in Figure 2) is compliance with the rules for the operation of solid waste landfills. In the case of landfills in Russia, this is not common.

\section{Conclusions}

Despite the fact that visual detection of solid waste landfills (in the Google Earth program) is carried out manually, its aspects can be systematized into steps and procedures that carry a clear sequence of actions from one point (input data) to another (output, required results). With visual detection of litter objects, you can determine: tasks, methods and algorithms defined by certain flowcharts. Such an approach will provide a solution for a more wider range of tasks for monitoring solid waste landfills than for automated monitoring methods, together with greater operational efficiency and less timeconsuming processing of data.

\section{References}

1. M.A. Shahramanian, A.A. Richter, Methods and technologies of space monitoring of waste disposal facilities in the interests of ensuring the ecological safety of the territory: Teaching-methodical manual (Center of the Russian State University of Oil and Gas, named after I.M. Gubkin, Moscow 2013)

2. A.A. Richter, M.A. Shahramanyan, M.L. Kazaryan, A.B., Fundamental research., no.2, 2866-2870 (2015)

3. A.A.Richter, M.A. Shahramanyan, M.L. Kazaryan, A.B., Fundamental research, no.2, 3095-3099 (2015)

4. K.D. Pamfilov, Instructions for the design, operation and reclamation of landfills for solid domestic waste (Ministry of Construction of the Russian Federation. Academy of Public Utilities, Moscow 1998) [in Russian]

5. V.G.Bondur, A.B. Murynin, A.A. Richter, M.A. Shahramanyan, Izvestiya SFU Technical science no.6, 131-134 (2012)

6. A.A. Richter, M.A. Shahramanyan, M.L. Kazaryan: Bulletin of the Vladikavkaz Scientific Center, no.3, 61-67 (2015)

7. A.V. Abrosimov, D.B. Nikolsky, L.V. Sheshukova, Ecology of urbanized territories, no. 1, 38-43 (2014)

8. S.S.Timofeeva, S.S.Timofeev., L.V. Sheshukova: Bulletin of the Irkutsk State Technical University, no. 2 84-88 (2013)

9. D.A. Lipilin, Fundamental research, 621-625 (2013)

10. A.V. Pogorelov, D.A. Lipilin. Proceedings of the Dagestan State Pedagogical University. Natural and exact sciences, no. 1, 114-121 (2014)

11. D.A. Lipilin. In Proc. Fifth International Scientific and Practical Conference. 186-189, (2013) 
12. O.V. Brovkina, D.Yu. Skoropisov, Modern problems of remote sensing of the Earth from space, no.1, 153155 (2012)

13. O.V. Brovkina: Earth exploration from space, no.6, 22-28 (2007)

14. I.V. Galitskaya, Geoecology, engineering geology, hydrogeology, geocryology no. 2, 144-147 (2005)

15. I.V.Galitskaya, Geoecology, engineering geology, hydrogeology, geocryology, no. 3, 225-237 (2007)

16. V.S. Putilina, I.V.Galitskaya, T.I. Yuganova: Ecology. A series of analytical reviews of world literature, no. 76, 1-100 (2005)

17. K.E. Levtin, Bulletin of the Siberian State Aerospace University. no. 3, 46-51 (2012)

18. V.I. Protsenko, N.L.Kazansky, P.G. Serafimovich, Computational Optics, no.4, 582-591 (2015)

19. V.M. Pavleichik, The collection: Steppes of Northern Eurasia Materials of the VII International Symposium, 603-608 (2015)

20. K.E. Levtin, Reshetnev Readings, no. 13, 514-515 (2009) 